УДК 504.3.054

\title{
МОНИТОРИНГ АЭРОТЕХНОГЕННОГО ВОЗДЕЙСТВИЯ СЫКТЫВКАРСКОГО ЛЕСОПРОМЫШЛЕННОГО КОМПЛЕКСА
}

\author{
Василевич Мария Ивановна 1 , \\ mvasilevich@ib.komisc.ru
}

\author{
Кондратёнок Борис Михайлович 1 , \\ kondratenok@ib.komisc.ru
}

Очеретенко Дмитрий Петрович², dmitry.ocheretenko@mondigroup.com

\author{
Василевич Роман Сергеевич1, \\ vasilevich.r.s@ib.komisc.ru
}

Габов Дмитрий Николаевич 1 , gabov@ib.komisc.ru

\author{
Лодыгин Евгений Дмитриевич1, \\ lodigin@ib.komisc.ru \\ 1 Институт Биологии ФИЦ КомиНЦ УрО РАН, \\ Россия, 167982, г. Сыктывкар, ул. Коммунистическая, 28. \\ 2 АО «Монди СЛПК», \\ Россия, 167026, Сыктывкар, пр. Бумажников, 2.
}

\begin{abstract}
Актуальность исследования обусловлена необходимостью оценки уровня воздействия крупного целлюлозно-бумажного предприятия, расположенного к северу от г. Сыктывкара, на основе экохимического анализа зимних атмоссрерных осадков (снега), продемонстрировать иелесообразность применения такого подхода в экологических исследованиях.

Цель: показать динамику аэротехногенной нагрузки на территорию вблизи АО «Монди СЛПК» по данным о химическом составе снежного покрова за период мониторинга.

Объекты: образцы снежного покрова, отобранные в зоне воздействия предприятия и на условно фоновых территориях. Методы: снегосъемка с использованием трансект на постоянных пунктах отбора проб, применение аналитических методов согласно руководству по контролю загрязнения атмоссреры (РД 52.04.186-89), картографические методы оценки распространения загрязнения в снежном покрове с использованием метода интерполяции (метод обратных взвешенных расстояний), применение алгебры карт для расчета площадей зон воздействия.

Результаты. Представлены результаты экохимического мониторинга снежного покрова в зоне воздействия выбросов АО «Монди СЛПК» за многолетний период. Дана общая характеристика распределения компонентов выбросов относительно источника эмиссии. Мониторинг снежного покрова в импактной зоне предприятия позволил провести анализ динамики аэротехногенной нагрузки. Результаты расчета поступления веществ на территорию предприятия в 2019 г. показали наиболее низкий уровень загрязнения снежного покрова за весь период наблюдений, 66 \% относительно объемов 2002 г. Отмечено снижение поступления загрязнителей, начиная с 2016 г. после реконструкции предприятия. Концентрации примесей в талой воде за пределами санитарно-защитной зоны не превышали санитарно-гигиенических нормативов. По данным мониторинга снежного покрова показан тренд к снижению аэрогенного воздействия.
\end{abstract}

Ключевые слова:

Снежный покров, экохимический мониторине, целлюлозно-бумажное предприятие, динамика и зоны воздействия

\section{Введение}

При проведении экохимического мониторинга важным является выбор природных объектов для исследования. Качество атмосферного воздуха длительное время изучается посредством исследования химического состава атмосферных осадков. Химический состав атмосферных осадков широко используют для оценки загрязненности атмосферы, т. к. концентрация химических веществ в атмосферных осадках коррелирует с их концентрацией в воздухе $[1,2]$ Снежный покров способен сохранять и накапливать вещества, поступающие на его поверхность из атмосферы, что позволяет проводить интегральные оцен- ки загрязненности территорий за длительные временные периоды [3]. Анализ научных публикаций по геоэкологическим исследованиям урбанизированных территорий свидетельствует о том, что загрязненность снежного покрова отражает степень антропогенного воздействия на окружающую среду [4, 5]. Поэтому химический состав снежного покрова находит широкое применение в мониторинговых исследованиях аэрогенного воздействия промышленных предприятий на окружающую среду [6-11].

Современные картографические методы обработки данных [12] позволяют по результатам количественного химического анализа проб снежного по- 
крова установить закономерности распределения поллютантов, входящих в состав газопылевых выбросов, выявить источники загрязнения и ареалы их влияния, дифференцировать территорию по уровню техногенного воздействия, оценить количество токсикантов, выносимое талыми водами в поверхностные водоемы и мигрирующее в почвы и подземные воды [13].

Исследования были проведены на территории, расположенной в зоне аэротехногенного воздействия $\mathrm{AO}$ «Монди СЛПК» (СЛПК) - одного из крупнейших предприятий целлюлозно-бумажного производства в европейской части России. С 2002-2003 гг. на предприятии начались работы по изменению технологических процессов и модернизации очистных сооружений с целью снижения воздействия на окружающую среду. За 2004-2006 гг. произошло снижение выбросов в атмосферу по взвешенным веществам за счет установки электрофильтра, а также, в связи с переходом на бесхлорную отбелку, исключено применение элементарного хлора. В 2008 г. на предприятии была начата программа по модернизации «STEP». Построен новый содорегенерационный котел, система сбора дурнопахнущих газов от производства целлюлозы, установлен электрофильтр на регенерационную печь, известерегенерационная печь № 3 переведена на обжиг извести. Также проведены другие работы по модернизации, которые продолжаются до настоящего времени. Все эти мероприятия к настоящему времени позволили снизить выбросы в атмосферу взвешенных веществ, дурнопахнущих газов, серосодержащих веществ, оксида углерода, а также хлора и двуокиси хлора.

Таким образом, улучшились многие показатели по воздуху и стали значительно ниже допустимых нормативов. В связи с этим было целесообразно провести анализ изменения динамики загрязнения по показателям химического состава снежного покрова в зоне эмиссии.

Мониторинг химического состава снежного покрова на территории промышленной площадки СЛПК и прилегающих территориях проводили в 2002-2007, 2016, 2018 и 2019 гг. Цель настоящей работы показать динамику аэротехногенной нагрузки на территорию вблизи СЛПК по данным о химическом составе снежного покрова за весь период мониторинга.

\section{Объекты и методы}

Территория исследования расположена в орографической области Вычегодско-Мезенской равнины, в юго-западной части Республики Коми на левом берегу реки Вычегды, в 18 км на север от г. Сыктывкара, в Эжвинском районе города. Климат местности умеренно континентальный, с непродолжительным, но достаточно тёплым летом и с многоснежной, продолжительной и умеренно-холодной зимой. Годовое суммарное выпадение осадков составляет 560 мм. Преобладающее направление ветра для данной местности - юго-западное и южное [14].

Отбор проб снега проводили непосредственно на территории СЛПК, на границе санитарно-защитной зоны (С33), а также на участках, расположенных в соответствии с характерной для данной местности «розы ветров» с преобладанием в зимнее время ветров южного и юго-западного направлений. Отбор проб снега осуществляли в период максимального снегонакопления и до начала снеготаяния - в I и II декадах марта. Отбор проб снежного покрова проводили на постоянных ключевых пунктах наблюдения с незначительным варьированием расположения точек отбора проб (рис. 1).

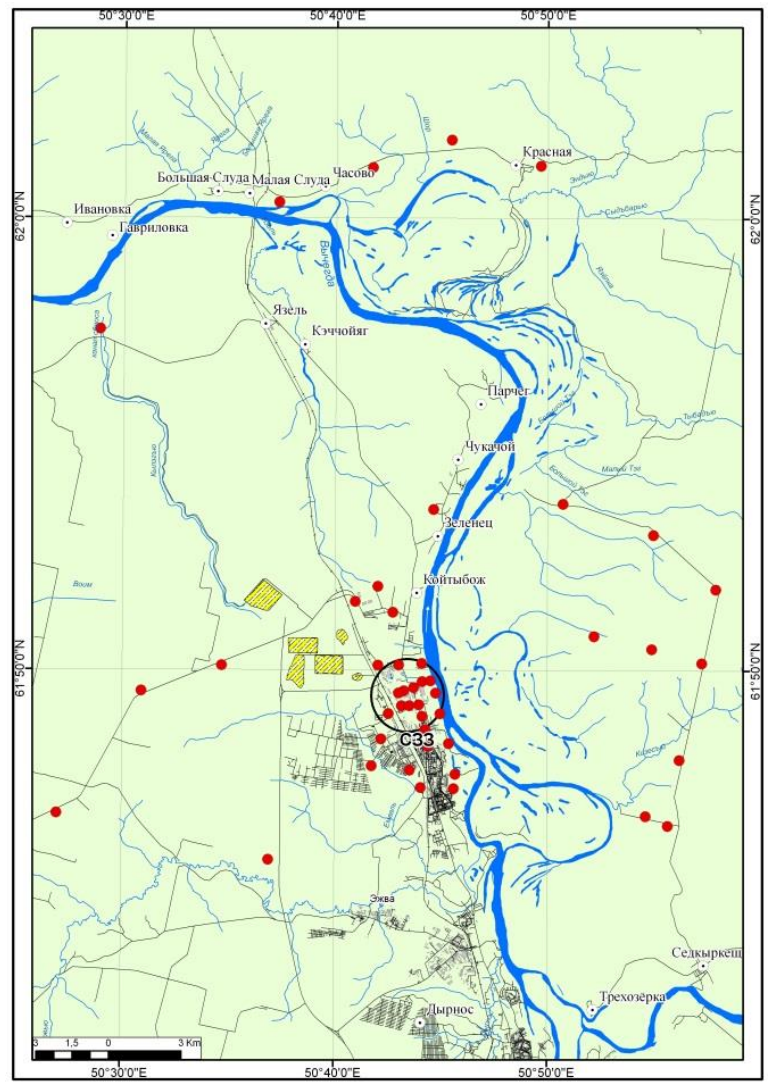

Puc. 1. Схема отбора образиов снежного покрова в 2019 г.

Fig. 1. Snow cover sampling scheme in 2019

Всего за весь период мониторинга было отобрано 446 проб снежного покрова, в среднем за сезон - около 50 проб.

Отбор проб проводили пластиковой трубой, на внешней поверхности которой были нанесены деления для замера высоты снежного покрова. В намеченных точках пробоотбора с площади 8-10 м² отбирали смешанную пробу - 5-20 снежных кернов в один общий для данной точки полиэтиленовый пакет, предварительно промытый бидистиллированной водой. Во избежание загрязнения проб снежного покрова частицами почвы нижнюю часть кернов (1-2 см) отбрасывали. Пробы снежного покрова взвешивали с точностью 0,005 кг и хранили до проведения анализа в твердом состоянии при температуре минус $30{ }^{\circ} \mathrm{C}$. Масса отдельной пробы с каждого участка отбора составляла от 3 до 3,5 кг.

На первом этапе пробоподготовки образцы снега растапливали при комнатной температуре в тщатель- 
но промытых бидистиллятом пластиковых емкостях. В нефильтрованных пробах был проведен анализ водородного показателя (pH), удельной электропроводности, химического потребления кислорода (ХПК). После стабилизации температуры талых вод на уровне комнатной пробы фильтровали через мембранные ацетат-целлюлозные фильтры Владипор $(d=0,47$ мм). В полученном фильтрате измеряли массовую концентрацию тяжелых металлов, микро- и макроэлементов, углерода органических соединений и гидрокарбонат-ионов, общего азота и азотсодержащих соединений (нитрат-, нитрит-, аммоний-ионов), фенола, полициклических ароматических углеводородов (бенз(а)пирен).

Количественный химический анализ (КХА) проб талой воды был проведен в аккредитованной экоаналитической лаборатории Института биологии ФИЦ Коми НЦ УрО РАН (выписка из реестра аккредитованных лиц (аттестат аккредитации) № РОСС RU.0001.511257). Все исследования, включая отбор проб, хранение образцов снежного покрова, их химический анализ, были выполнены в соответствии с действующими нормативными документами.

Для более корректной интерпретации результатов эксперимента полученные данные пересчитывали в соответствующие значения массовой концентрации каждого компонента в снеге на единицу площади, используя следующую формулу:

$$
P=\frac{c_{m} V}{S n} 10,
$$

где $P$ - масса определяемого компонента, поступившего на единицу площади поверхности земли за весь

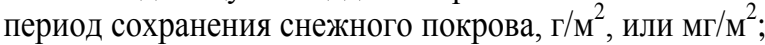
$c_{m}-$ массовая концентрация компонента в талой воде, мг/дм ${ }^{3}$, или мкг/дм ${ }^{3} ; V$ - объем талой воды всей пробы, дм ${ }^{3} ; S$ - площадь внутреннего поперечного сечения трубы для отбора проб снега, $\mathrm{cm}^{2} ; n$ - число кернов снежного покрова, отобранных в данной точке; 10 - коэффициент для согласования размерности.

Для построения тематических цифровых карт исследуемой территории в качестве основы использовали топографические карты ГосГисЦентра (ГГЦ) масштаба 1:200000, предназначенные для открытого пользования [15], переведенные в проекцию WGS 84, UTM. Оцифровку карт и создание карта-схем проводили в программном пакете Arc GIS 9.2. Статистическую обработку данных проводили с использованием программ Arc GIS 9.2, STATISTICA 6.0 и Erdas Imagine 10.0.

\section{Обсуждение результатов}

Состав газопылевых выбросов целлюлознобумажного комбината представлен в табл. 1. Основные компоненты в выбросах - оксиды серы, углерода, азота, карбонатно-сульфатная пыль [16]. Преобладающими показателями загрязнения в жидкой фазе являются $\mathrm{Na}^{+}, \mathrm{SO}_{4}{ }^{2-}$ (при условии перехода сульфата натрия при эмиссии в растворимые сульфаты), $\mathrm{NH}_{4}{ }^{+}$, $\mathrm{NO}_{2}{ }^{-}, \mathrm{NO}_{3}{ }^{-}$.
Таблица 1. Основной элементный и компонентный состав выбросов предприятия

Table 1. Basic element and component composition of the company's emissions

\begin{tabular}{|c|c|}
\hline $\begin{array}{c}\text { Компоненты выбросов } \\
\text { Components of the emission }\end{array}$ & $\begin{array}{l}\text { Элемент } \\
\text { Element }\end{array}$ \\
\hline $\begin{array}{c}\mathrm{SO}_{2}, \mathrm{SO}_{4}{ }^{2-}, \mathrm{H}_{2} \mathrm{~S}, \mathrm{CH}_{3} \mathrm{SH},\left(\mathrm{CH}_{3}\right)_{2} \mathrm{~S}, \\
\mathrm{CH}_{3} \mathrm{~S}-\mathrm{SCH}_{3}\end{array}$ & $\mathrm{~S}$ \\
\hline $\mathrm{NO}, \mathrm{NO}_{2}, \mathrm{NH}_{3}, \mathrm{NO}_{2}^{-}, \mathrm{NO}_{3}^{-}$ & $\mathrm{N}$ \\
\hline $\begin{array}{c}\mathrm{CO}_{2}, \mathrm{CO}, \mathrm{HCO}_{3}^{-}, \mathrm{CO}_{3}{ }^{2-}, \mathrm{C} \text { (ca- } \\
\text { жa/soot) }\end{array}$ & $\mathrm{C}$ \\
\hline $\begin{array}{c}\mathrm{Cl}, \mathrm{PO}_{4}{ }^{3-}, \\
\mathrm{SiO}_{3}{ }^{2-}, \mathrm{Na}^{+}, \mathrm{K}^{+}, \mathrm{Ca}^{2+}, \\
\mathrm{Mg}^{2+}\end{array}$ & $\mathrm{Cl}, \mathrm{P}, \mathrm{Si}, \mathrm{Na}, \mathrm{K}, \mathrm{Ca}, \mathrm{Mg}$ \\
\hline $\begin{array}{l}\text { Малорастворимые соединения } \\
\text { Low-soluble compounds }\end{array}$ & $\mathrm{Al}, \mathrm{Fe}$ \\
\hline $\begin{array}{l}\text { Не исследованы } \\
\text { Not investigated }\end{array}$ & $\begin{array}{c}\text { Микроэлементы } \\
\text { Trace elements } \\
\text { ( } \mathrm{Zn}, \mathrm{Cu}, \mathrm{Ni}, \mathrm{Pb}, \mathrm{Cd} \text { и др.) }\end{array}$ \\
\hline
\end{tabular}

Уровень техногенного воздействия предприятия оценивали путем сопоставления уровней поступления веществ на поверхность исследованной территории с фоновыми значениями. Картографический анализ рассеивания выбросов СЛПК показал, что максимальное распространение этих компонентов происходит на расстоянии до 18 км. В качестве условно фоновых уровней поступлений определяемых компонентов были взяты результаты измерений для проб снежного покрова, отобранные на территории в 22 км от источника эмиссии (д. Красная). Проводили оценку поступления веществ главным образом на территорию С33, условно очерченной вокруг основного источника эмиссии предприятия радиусом 1,5 км.

Степень единообразия в распределении компонентов относительно источника эмиссии оценивали по значениям корреляционных коэффициентов $(r)$ между массивами полученных экспериментальных данных. Закономерности распространения компонентов за весь период наблюдений в основном неизменны, о чем свидетельствуют близкие значения коэффициентов корреляции для сравниваемых массивов данных модулей поступлений на подстилающую поверхность (табл. 2).

Анализ средних значений коэффициента корреляции позволил выявить общие закономерности в распределении компонентов снежного покрова в зоне техногенеза: основная доля макро- и микрокомпонентов имеет единые механизмы распространения.

Большое значение в исследованиях было уделено анализу распределения интегральных показателей удельной электропроводности и водородному показателю. Характеристика электропроводности талой воды, безусловно, является индикатором техногенной нагрузки на территорию. Максимальные значения электропроводности отмечены непосредственно в импактной зоне предприятия (более $200 \mathrm{мкСм/см),} \mathrm{что}$ связано с наличием в талой воде растворимых солей.

Высокие значения коэффициентов корреляции отмечены между электропроводностью и основными ионами, за исключением нитрат-ионов и ионов аммония. Вблизи целлюлозно-бумажного комбината возрастают средние содержания сульфат-ионов и ионов натрия $\left(r_{\mathrm{Na}}{ }^{+}-\mathrm{SO}_{4}{ }^{2-}=0,71\right.$, при $\left.p=0,95\right)$. Кислотность та- 
лой воды отражает уровень техногенной эмиссии и является индикатором промышленного воздействия [17]. Высокое содержание в выбросах карбонатов и оксидов кальция и магния, дальнейшее их растворение приводят к возрастанию значений $\mathrm{pH}$. Значение pH по мере роста техногенного воздействия в 2019 г. достигало 8,4 при максимальном значении 9,6 в 2005 г. (рис. 2). На фоновых территориях таежной зоны среднее значение водородного показателя составляет 4,8. Наблюдается значимая взаимосвязь между величиной $\mathrm{pH}$ и общей минерализацией снеговой воды. Эти интегральные показатели коррелируют между собой: $\mathrm{r}_{\mathrm{pH}-\mathfrak{x}}=0,65-0,81$ (0,83 в 2019 г.).

Таблица 2. Коэффициенты корреляции между массивами значений модулей поступлений веществ в растворенной форме (фильтрат) на подстилаюшую поверхность

Table 2. Correlation coefficients between the arrays of values of the modules of the intake of substances in dissolved form (filtrate) on the underlying surface

\begin{tabular}{|c|c|c|c|c|c|}
\hline \multirow[b]{2}{*}{ 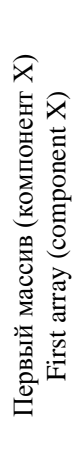 } & \multirow[b]{2}{*}{ 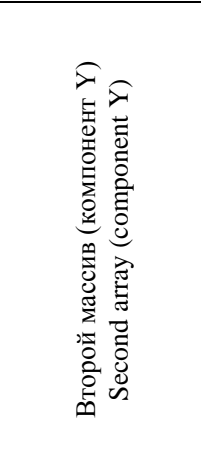 } & \multicolumn{4}{|c|}{$\begin{array}{c}\text { Коэффициент корреляции } \\
\text { Correlation coefficient } r(\mathrm{X}-\mathrm{Y})\end{array}$} \\
\hline & & 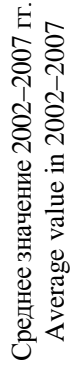 & 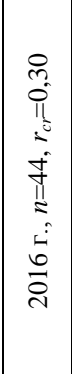 & 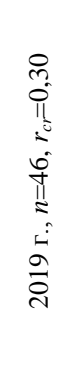 & 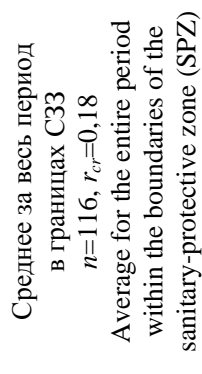 \\
\hline $\mathrm{Na}^{+}$ & $\begin{array}{c}\text { Удельная элек- } \\
\text { тропроводность } \\
\text { Electrical } \\
\text { conductivity } \\
\end{array}$ & 0,92 & 0,93 & 0,74 & 0,92 \\
\hline $\mathrm{Na}^{+}$ & $\mathrm{HCO}_{3}^{-}$ & 0,85 & 0,76 & 0,71 & 0,79 \\
\hline $\mathrm{Na}^{+}$ & $\mathrm{K}^{+}$ & 0,86 & 0,82 & 0,82 & 0,87 \\
\hline $\mathrm{Na}^{+}$ & $\mathrm{NO}_{2}^{-}$ & 0,73 & 0,80 & 0,62 & 0,48 \\
\hline $\mathrm{Na}^{+}$ & $\mathrm{Ca}^{2+}$ & 0,68 & \begin{tabular}{|l|}
0,58 \\
\end{tabular} & 0,58 & 0,43 \\
\hline $\mathrm{Na}^{+}$ & $\mathrm{SO}_{4}{ }^{2-}$ & 0,80 & 0,66 & 0,79 & 0,71 \\
\hline $\mathrm{pH}$ & $\mathrm{SO}_{4}{ }^{2-}$ & 0,80 & 0,65 & 0,74 & 0,48 \\
\hline $\mathrm{NO}_{2}{ }_{2}^{-}$ & $\mathrm{NO}_{3}{ }^{-}$ & 0,02 & \begin{tabular}{|l|l|}
0,34 \\
\end{tabular} & 0,09 & 0,25 \\
\hline $\mathrm{Cu}^{2+}$ & $\mathrm{Cd}^{2+}$ & 0,33 & 0,17 & - & 0,25 \\
\hline $\mathrm{Cu}^{2+}$ & $\mathrm{Zn}^{2+}$ & 0,33 & \begin{tabular}{|l|l|}
0,47 \\
\end{tabular} & 0,32 & 0,46 \\
\hline $\mathrm{Cu}^{2+}$ & $\mathrm{Ni}^{2+}$ & 0,21 & 0,16 & $\begin{array}{l}0,1 \\
\end{array}$ & 0,06 \\
\hline $\mathrm{Ni}^{2+}$ & $\mathrm{Cd}^{2+}$ & 0,20 & \begin{tabular}{|l|l|} 
\\
\end{tabular} & - & 0,50 \\
\hline
\end{tabular}

- нет данных/no data available.

Корреляционный анализ показывает общность поступления основных компонентов загрязнения территории С33: ионов натрия, кальция, калия и магния, сульфат-, хлорид-, гидрокарбонат-ионов, серы и фосфора.

Основное количество перечисленных компонентов осаждается в импактной зоне. Нитрат-ионы распространяются исключительно в составе аэрозолей. Поэтому в рабочей и С33 получены минимальные значения модулей поступления нитрат-ионов, осаждение которых происходит лишь на расстоянии 5-7 км от источника газовых выбросов.
Расчет соотношения молярных концентраций эквивалентов главных ионов позволил показать баланс их содержания в талых водах при изменении воздействия эмиссии (табл. 3).

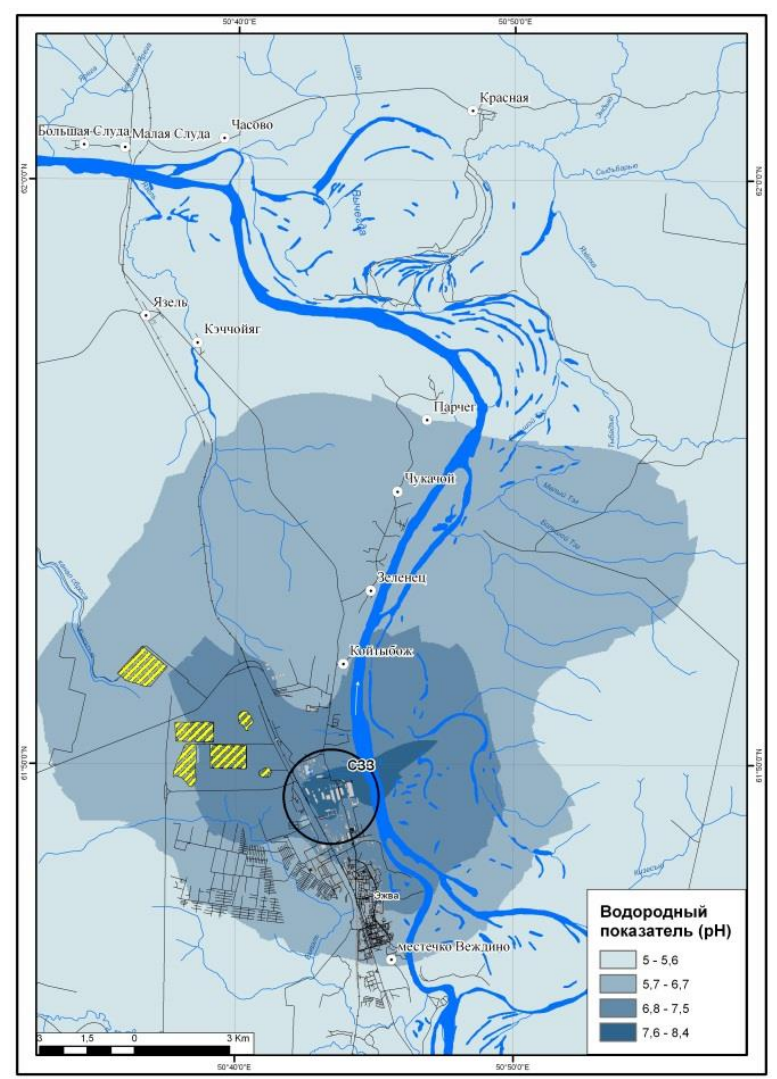

Pис. 2. Карта-схема распределения значений водородного показателя (рH) в талой воде (2019 г.)

Fig. 2. Map-diagram of distribution of the hydrogen index (pH) values in meltwater (2019)

Таблица 3. Соотношения молярных концентраций эквивалентов (моль-экв/ $/ \mathrm{M}^{3}$ ) главных ионов $в$ жидкой фазе талой воды

Table 3. Ratios of molar concentrations of equivalents $\left(\right.$ mol-eq/dm $\left.{ }^{3}\right)$ of the main ions in the liquid phase of meltwater

\begin{tabular}{|c|c|c|c|}
\hline $\begin{array}{c}\text { Показатель } \\
\text { Indicator }\end{array}$ & $\begin{array}{c}\text { C33 } \\
\text { SPZ }\end{array}$ & $\begin{array}{c}\text { Фон } \\
\text { Background } \\
\text { territory }\end{array}$ & $\begin{array}{c}\text { Граница } \\
\text { C33 } \\
\text { SPZ border }\end{array}$ \\
\hline $\mathrm{pH}$ & 7,6 & 5,0 & 7,0 \\
\hline $\mathrm{pHa}$ & 4,2 & 4,7 & 4,3 \\
\hline$\left[\mathrm{SO}_{4}^{2-}\right] /\left[\mathrm{NO}_{3}{ }^{-}\right]$ & 46 & 0,93 & 2,0 \\
\hline$\left[\mathrm{NH}_{4}{ }^{+}\right]+\left[\mathrm{Ca}^{2+}+\left[\mathrm{Mg}^{2+}\right]+\left[\mathrm{Na}^{+}\right]+\left[\mathrm{K}^{+}\right]\right.$ & 5,0 & 1,05 & 3,5 \\
\hline$\left[\mathrm{SO}_{4}{ }^{2-}\right]+\left[\mathrm{NO}_{3}{ }^{-}\right]+\left[\mathrm{Cl}^{-}\right]$ & & 0,9 & 4,7 \\
\hline$\left(\left[\mathrm{Ca}^{2+}\right]+\left[\mathrm{Mg}^{2+}\right]\right) /\left[\mathrm{SO}_{4}{ }^{2-}\right]$ & 5,3 & 0,9 & 5,0 \\
\hline$\left[\mathrm{SO}_{4}{ }^{2-}\right] /\left[\mathrm{Cl}^{-}\right]$ & 5,9 & 3,5 &
\end{tabular}

С использованием средних значений концентраций сульфатов и нитратов, а также хлорид-ионов, вклад которых на территории С33 значим в талой воде, рассчитана кислотность $\mathrm{pHa}=-\lg \left(\left[\mathrm{SO}_{4}{ }^{2-}\right]+\left[\mathrm{NO}_{3}{ }^{-}\right]+\left[\mathrm{Cl}^{-}\right]\right)$, которая по своему физическому смыслу соответствует pH осадков при условии, что в них не происходит нейтрализации щелочными компонентами.

Значения рНа и $\mathrm{pH}$ обычно рассматриваются при обсуждении кислотно-основных свойств атмосфер- 
ных осадков [18]. Рассчитанные величины кислотности талых вод указывают на значительную степень нейтрализации анионов в зоне наибольшего воздействия выбросами предприятия. В то время как на более удаленных и фоновых территориях значения $\mathrm{pH}$ и рНа близки вследствие снижения доли нейтрализующих компонентов.

Более значимую роль в формировании кислотности снеговых вод играют ионы $\mathrm{SO}_{4}{ }^{2-}$, ч чем свидетельствуют высокие значения отношения $\left(\left[\mathrm{SO}_{4}{ }^{2-}\right] /\left[\mathrm{NO}_{3}{ }^{-}\right]\right)>1$. Coдержание хлоридов в снеге невелико, и его влияние на кислотные свойства незначительно. Соотношение катионов к анионам еще раз показало, что загрязняющие компоненты имеют подщелачивающие свойства, влияя на рН не только атмосферных осадков, но и почв и грунтовых вод. Содержание катионов в границах СЗ3 в 15 раз превышает фоновый уровень.

Показателем техногенной эмиссии служит отношение $\left[\mathrm{SO}_{4}{ }^{2}\right] /\left[\mathrm{Cl}^{-}\right]$в талой воде, которое в зоне техногенного воздействия может достигать 10 [19]. Полученные данные показали, что на фоновых территориях таежной зоны соотношение $\left[\mathrm{SO}_{4}{ }^{2-}\right] /\left[\mathrm{Cl}^{-}\right]$в среднем составляет 4,4 (3,5 на условных фоновых участках вблизи д. Красная) [20]. В зоне наибольшего воздействия СЛПК возрастает до 38.

Рачеты показали, что наблюдается изменение соотношения основных ионов. Так, в снеге импактной зоны предприятия преобладают ионы натрия. На фоновых территориях преобладающими катионами выступают ионы кальция. Содержание натрия в талой

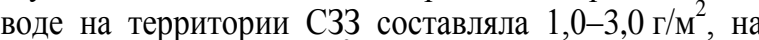

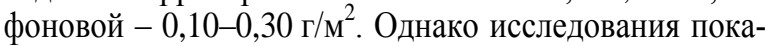
зали динамику снижения содержания данного поллютанта в снеге СЗ3 за период мониторинга.

Геохимические ряды макрокомпонентов в снеге импактной (1) и фоновых территорий (2) различаются: $\mathrm{Na}^{+}>\mathrm{Ca}^{2+}>\mathrm{K}^{+}>\mathrm{Mg}^{2+}>\mathrm{NH}_{4}{ }^{+} / \mathrm{HCO}_{3}{ }^{-}>\mathrm{SO}_{4}{ }^{2-}>\mathrm{Cl}^{-}>\mathrm{NO}_{3}{ }^{-}>\mathrm{NO}_{2}{ }^{-}$

$$
\begin{aligned}
& 20>7>2>1>1 / 132>85>19>15>1 \\
& \mathrm{Ca}^{2+}>\mathrm{Na}^{+}>\mathrm{NH}_{4}^{+}>\mathrm{Mg}^{2+}>\mathrm{K}^{+} / \mathrm{SO}_{4}{ }^{2-}>\mathrm{NO}_{3}{ }^{-}>\mathrm{Cl}^{-}>\mathrm{NO}_{2}{ }^{-} \\
& 29>23>13>6>1 / 4>4>1>0,05
\end{aligned}
$$

В составе выбросов СЛПК основное место занимают пыль и растворимые соли. Результаты исследований показали, что имеет место также локальное загрязнение территории микроэлементами. Распределения тяжелых металлов $\mathrm{Fe}, \mathrm{Cu}, \mathrm{Ni}, \mathrm{Pb}, \mathrm{Cd}, \mathrm{Zn}$ в снеге вокруг СЛПК не имели постоянных четко выраженных зависимостей. Для данных компонентов отмечали невысокие значения коэффициентов корреляции как с макрокомпонентами, так и между собой. Корреляционный анализ данных отдельно в пределах С33 показал более достоверные взаимосвязи между поступлением тяжелых металлов: $R_{\mathrm{Cu}-\mathrm{Zn}}=0,46$, $r_{\mathrm{Ni}-\mathrm{Cd}}=0,50$. Отмечено, что на характер распределения $\mathrm{Pb}, \mathrm{Cd}, \mathrm{Ni}$ в основном влияют факторы, несвязанные с выбросами СЛПК (автотранспорт и автотранспортные предприятия, стройиндустрия, жилищнокоммунальный сектор). Однако максимальные содержания $\mathrm{Mn}, \mathrm{Zn}, \mathrm{Ni}, \mathrm{Al}, \mathrm{V}$ наблюдаются в снежном покрове территории в пределах С33. Высокие значе- ния содержания марганца на территории С33 обусловлены содержанием его соединений в отходах переработки хвойной древесины, что делает марганец маркером выбросов СЛПК. Содержания $\mathrm{Mn}, \mathrm{Zn}, \mathrm{Cu}$, $\mathrm{Ni}$ и $\mathrm{V}$ превышают фоновые значения в 12, 3, 2, 4 и 4 раза соответственно за последние периоды наблюдений в 2016 и 2019 гг.

Нужно отметить, что в сравнении с 2005 г., когда проводился анализ ПАУ в снеге на территории С33 и вокруг предприятия, в 2016 г. уровень загрязнения полиаренами сократился более чем в 2 раза, однако среднее содержание в снеге наиболее опасного компонента - бенз[а]пирена - осталось на том же уровне $\left(0,66\right.$ мкг $\left./ \mathrm{m}^{2}\right)$. Максимум его поступления отмечен на территории С33. В 2019 г. его содержание на границе С33 составило 3,4 мкг $/ \mathrm{M}^{2}$, как и в 2018 г. Результаты распределения бенз(а)пирена показали, что более высокие содержания полиаренов наблюдались в снеге Эжвинского района (рис. 3).

Степень техногенного воздействия ПАУ оценивали на основе сопоставления уровней поступления ПАУ на подстилающую поверхность аэротехногенных и фоновых ландшафтов. Если модули поступления суммы ПАУ на территории импактной зоны предприятия в 2016 г. превышали фоновые значения для целлюлозно-бумажного комбината в среднем в 10 раз, на границе С33 в среднем - 5 раз, то в 2019 г. кратность поступления бенз[а]пирена над фоновым составила 20 раз. Так, значения содержания бенз(а)пирена на территории С33 наблюдались в диапазоне 1,6-5,3 мкг/м². На фоновой территории 0,20 мкг/ $\mathrm{M}^{2}$.

Наиболее важно для оценки аэрогенного воздействия знать уровень поступления компонентов на территорию СЗ3 СЛПК (табл. 4).

Для этого рассчитывали значение содержания каждого компонента в снеге С33 и их суммарное содержание за каждый год наблюдений. Расчеты показали, что общий объем выбросов на территорию С33 в 2003 г. составил 77 \% относительно 2002 г., в 2004 г. - 87 \%. В среднем за два года (2003, 2004 гг.) уменьшение выбросов составило $18 \%$ относительно 2002 г. за счет гидрокарбонат-ионов, сульфатов-ионов, ионов натрия, калия.

Существенное снижение загрязнения связано с проведением в 2002 г. реконструкции газоочистных сооружений. Однако в 2005 г. наблюдалось резкое увеличение общего объема выбросов на территорию С33 на 28 \% в сравнении с 2002 г., что было обусловлено значительным увеличением производства. В 2006 и 2007 гг. уровень загрязнения снежного покрова СЗ3 был примерно одинаковым и составил $105 \div 107 \%$ от уровня 2002 г.

Результаты расчета модулей поступления веществ на территорию С33 предприятия 2016 г. после его масштабной реконструкции показали наиболее низкий уровень загрязнения снежного покрова за весь период наблюдений, 68 \% относительно объемов 2002 г.

Наиболее значимое снижение отмечалось для содержания в снеге сульфат-ионов, натрия, калия, которые являются основными компонентами загрязнения. 
Таблица 4. Модули поступления (Р) макро- и микрокомпонентов на территорию Сз3 СЛПК за период с 2002 по 2007 г2., в 2016, 2019 г2.

Table 4. Modules of receipt $(P)$ of macro- and micro-components to the territory of the SLPC SPZ for the period from 2002 to 2007, in 2016, 2019

\begin{tabular}{|c|c|c|c|c|c|c|c|c|c|c|c|c|c|c|c|c|}
\hline \multirow{2}{*}{$\begin{array}{c}\text { Макро- и микрокомпо- } \\
\text { ненты, }(\text { кг/км²) } \\
\text { Macro- and micro- } \\
\text { components, }\left(\mathrm{kg} / \mathrm{km}^{2}\right)\end{array}$} & \multicolumn{2}{|c|}{2002} & \multicolumn{2}{|c|}{2003} & \multicolumn{2}{|c|}{2004} & \multicolumn{2}{|c|}{2005} & \multicolumn{2}{|c|}{2006} & \multicolumn{2}{|c|}{2007} & \multicolumn{2}{|c|}{2016} & \multicolumn{2}{|c|}{2019} \\
\hline & $\mathrm{P}$ & $\%^{*}$ & $P$ & $\%$ & $P$ & $\%$ & $\mathrm{P}$ & $\%$ & P & $\%$ & $P$ & $\%$ & $\mathrm{P}$ & $\%$ & $P$ & $\%$ \\
\hline $\mathrm{SO}_{4}{ }^{2-}$ & 1840 & 22,05 & 1350 & 21,07 & 1606 & 22,10 & 3021 & 28,31 & 1838 & 20,93 & 1038 & 11,58 & 401 & 7,08 & 487 & 8,9 \\
\hline $\mathrm{Na}^{+}$ & 1360 & 16,30 & 830 & 12,96 & 980 & 13,49 & 2097 & 19,65 & 2081 & \begin{tabular}{|l|}
23,69 \\
\end{tabular} & 2288 & 25,53 & 407 & 7,18 & 241 & 4,4 \\
\hline $\mathrm{Ca}^{2+}$ & 400 & 4,79 & 450 & 7,02 & 670 & 9,22 & 807 & \begin{tabular}{|l|}
7,56 \\
\end{tabular} & 506 & 5,76 & 617 & 6,89 & 657 & 11,60 & 891 & 16,3 \\
\hline $\mathrm{K}^{+}$ & 290 & 3,48 & 190 & 2,97 & 260 & 3,58 & 314 & 2,94 & 233 & 2,66 & 252 & 2,81 & 86 & 1,52 & 114 & 2,09 \\
\hline $\mathrm{Mg}^{2+}$ & 50 & 0,60 & 60 & 0,94 & 59 & 0,81 & 100 & 0,93 & 29 & \begin{tabular}{|l|}
0,33 \\
\end{tabular} & 35 & \begin{tabular}{|l|}
0,39 \\
\end{tabular} & 32 & 0,56 & 62 & 1,13 \\
\hline $\mathrm{N}^{-\mathrm{NO}_{3}{ }^{-}}$ & 160 & 1,92 & 280 & 4,37 & 28 & 0,39 & 32 & 0,30 & 43 & \begin{tabular}{|l|}
0,49 \\
\end{tabular} & 8 & \begin{tabular}{|l|}
0,09 \\
\end{tabular} & 24 & \begin{tabular}{|l|}
0,43 \\
\end{tabular} & 25 & 0,45 \\
\hline $\mathrm{N}-\mathrm{NO}_{2}^{-}$ & 7 & 0,08 & 5 & 0,08 & 7 & 0,10 & 8 & 0,08 & 6 & \begin{tabular}{|l|}
0,07 \\
\end{tabular} & 5 & 0,05 & 4,5 & 0,08 & 1,3 & 0,02 \\
\hline $\mathrm{HCO}_{3}^{-}$ & 4000 & 47,9 & 3000 & 46,8 & 3460 & 47,6 & 3935 & 36,9 & 3195 & 36,4 & 4239 & 47,3 & 3720 & \begin{tabular}{|l|}
65,7 \\
\end{tabular} & 3516 & 64,3 \\
\hline $\mathrm{N}-\mathrm{NH}_{4}{ }^{+}$ & 25 & 0,30 & 50 & 0,78 & 35 & 0,48 & 163 & 1,53 & 21 & \begin{tabular}{|l|}
0,21 \\
\end{tabular} & 0,22 & \begin{tabular}{|l|}
0,00 \\
\end{tabular} & 27 & \begin{tabular}{|l|}
0,47 \\
\end{tabular} & 53,7 & 0,98 \\
\hline $\mathrm{Cl}^{-}$ & 200 & 2,40 & 180 & 2,81 & 154 & 2,12 & 181 & 1,70 & 823 & \begin{tabular}{|l|}
9,37 \\
\end{tabular} & 321 & 3,6 & 301 & 5,3 & 68,0 & 1,24 \\
\hline $\mathrm{Mn}$ & 6,5 & 0,078 & 7,5 & 0,12 & 3,31 & 0,05 & 7,81 & 0,073 & 5,78 & 0,066 & 7,07 & 0,079 & 4,76 & 0,084 & 9,6 & 0,18 \\
\hline $\mathrm{Cu}$ & 0,32 & 0,004 & 0,15 & 0,23 & 0,3 & 0,004 & 0,16 & 0,002 & 0,12 & 0,001 & 0,45 & 0,005 & 0,06 & 0,001 & 0,14 & 0,003 \\
\hline $\mathrm{Ni}$ & 0,16 & 0,002 & 0,24 & 0,004 & 0,49 & 0,007 & 0,22 & 0,002 & 0,30 & 0,003 & 0,08 & 0,001 & 0,01 & 0,000 & 0,06 & 0,001 \\
\hline $\mathrm{Pb}$ & 0,106 & 0,001 & 0,121 & 0,002 & 0,09 & 0,001 & - & - & - & - & - & - & - & - & - & - \\
\hline $\mathrm{Cd}$ & 0,044 & 0,001 & 0,021 & 0,000 & \begin{tabular}{|l|}
0,149 \\
\end{tabular} & 0,002 & 0,06 & 0,001 & 0,30 & 0,003 & 0,004 & 0,000 & 0,01 & 0,000 & - & - \\
\hline $\mathrm{Zn}$ & 4,3 & 0,052 & 2,65 & 0,041 & 1,02 & 0,014 & 0,87 & 0,008 & 1,15 & 0,013 & 1,55 & 0,017 & 1,25 & 0,022 & 1,8 & 0,033 \\
\hline Фенолы/Phenols & 0,7 & 0,008 & 0,29 & 0,005 & 0,24 & 0,003 & 4,59 & 0,043 & 1,40 & 0,016 & 0,49 & 0,005 & 0,76 & 0,013 & 1,0 & 0,018 \\
\hline Итого/Total & 8344 & 100 & 6406 & 100 & 7266 & 100 & 10671 & 100 & 8782 & 100 & 8961 & 100 & 5667 & 100 & 5471 & 100 \\
\hline $\begin{array}{l}\text { Относительно суммарно- } \\
\text { го модуля поступления в } \\
2002 \text { г. } \\
\text { Relative to the total } \\
\text { admission module in } 2002\end{array}$ & 1,0 & 00 & 0 & 77 & ), & 87 & 1,2 & & & 05 & 1, & 07 & & 68 & & 66 \\
\hline
\end{tabular}

* - Доля компонента от общего суммарного модуля поступления всех приведенных компонентов/Share of the component from the total module of receipt of all the listed components.

Среди микрокомпонентов существенное снижение нагрузки отмечено для меди и никеля, которые не являются специфическими компонентами эмиссии данного предприятия. В 2019 г. модули поступления веществ на территорию С33 сохранились на уровне 2016 г. Отмечалось снижение в поступлении поллютантов доли ионов натрия и хлорид-ионов.

Большая разница в поступлении веществ между 2007 и 2016 гг. связана с модернизацией предприятия и успешным изменением в его технологических процессах.

Отдельно оценивали уровень загрязнения талых вод с территории предприятия органическими компонентами. Среднее значение ХПК в 2007 г. на территории С33 составило 40,3 мг О/дм ${ }^{3}$, в 2016 г. 28,4 мг О/дм ${ }^{3}$, в 2019 г. составило 14,5 мг О/дм². Нужно подчеркнуть, что по экспериментальным данным исследований в 2007 г. около 70 \% органических соединений - это нерастворимые в воде компоненты, в составе пылевых частиц, на это указывает сравнение данных по углероду, рассчитанному из значений ХПК (нефильтрованная проба), содержание которого на территории С33 1,7 г/м² и общему органическому углероду (фильтрованная проба = ТОС), содержание которого в снеге 0,5 г/ $\mathrm{m}^{2}$.
При том, что общее содержание органического углерода в снеге С33 значительно снизилось, присутствие фенолов остается постоянным в течение всего периода мониторинга, даже после модернизации, в 2016-2019 гг., отмечается поступление на уровне среднего за весь период мониторинга.

Таблица 5. Матрица коэффициентов коррелячии между органическими компонентами в снежном покрове

Table 5. Matrix of correlation coefficients between organic components in snow cover

\begin{tabular}{|c|c|c|c|c|}
\hline \multirow[t]{2}{*}{$\begin{array}{c}\text { Первый массив } \\
\text { (компонент X) } \\
\text { First array } \\
\text { (component X) }\end{array}$} & \multirow[t]{2}{*}{$\begin{array}{l}\text { Второй массив } \\
\text { (компонент Y) } \\
\text { Second array } \\
\text { (component Y) }\end{array}$} & \multicolumn{3}{|c|}{$\begin{array}{c}\text { Коэффициент } \\
\text { корреляции } \\
\text { Correlation coefficient } \\
r(\mathrm{X}-\mathrm{Y})\end{array}$} \\
\hline & & 2005 & 2016 & 2019 \\
\hline \multirow{2}{*}{$\begin{array}{l}\text { Сумма ПАУ } \\
\text { Amount of } \\
\text { polyarenes }\end{array}$} & $\begin{array}{c}\text { ХПК } \\
\text { Chemical oxygen } \\
\text { consumption }\end{array}$ & 0,63 & 0,78 & 0,54 \\
\hline & Фенол/Phenol & 0,79 & 0,73 & 0,35 \\
\hline \multirow[t]{2}{*}{$\begin{array}{c}\text { бенз[а]пирен } \\
\text { benz [a]pyrene }\end{array}$} & $\begin{array}{c}\text { ХПК } \\
\text { Chemical oxygen } \\
\text { consumption }\end{array}$ & 0,60 & 0,63 & 0,33 \\
\hline & Фенол/Phenol & 0,55 & 0,65 & $-^{*}$ \\
\hline
\end{tabular}

* - нет данных/no data available. 
Проведенные расчеты показали достаточно высокие значения коэффициента корреляции между массивами значений органического углерода (ХПК), содержанием фенола и суммарного содержания ПАУ и бенз(а)пирена (табл. 5), т. е. эти компоненты в снеге территории исследования характеризуются общим источником их поступления в окружающую среду. Подобные взаимосвязи проявляются у органических компонентов с общим содержанием органического вещества вблизи других источников эмиссии [21].

Анализ результатов по распределению ПАУ в снежном покрове как фоновой, так и техногенной территорий, показал наличие в нем в основном низкомолекулярных полиаренов, таких как фенантрен, флуорантен, пирен, хризен.

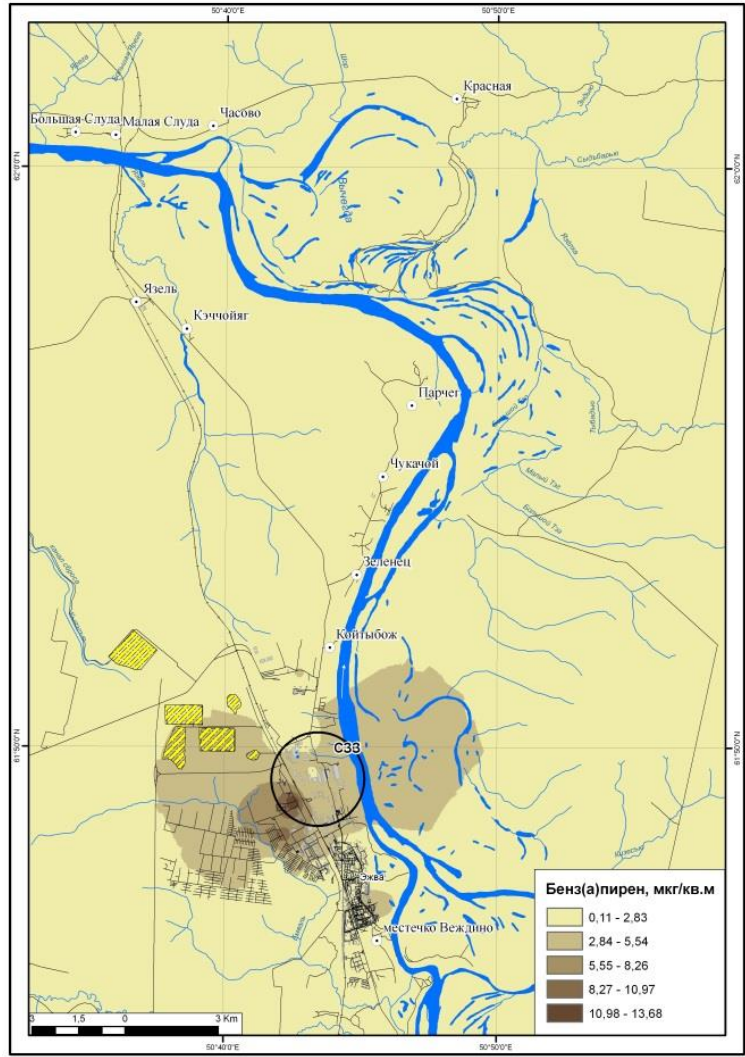

Рис.3. Карта-схема распределения содержания бенз(а)пирена в талой воде в 2019 г.

Fig. 3. Map-scheme of benz(a)pyrene content distribution in meltwater in 2019

Талые воды с территории С33 - одна из категорий вод, качество которых относительно общепринятых нормативов важно знать. Сравнение проводили с ПДК для вод рыбохозяйственного назначения $\left(П Д К_{\text {p.x. }}\right)$. Содержание большинства определяемых компонентов в талых водах было ниже ПДК р.х., в том числе в образцах снежного покрова с территории промзоны. Однако для некоторых компонентов весь период наблюдений повторялось превышение ПДК р.х. Наблюдалось превышение нормативов на территории С33 для нитрит-ионов (до 5,8 ПДК р.х.), для марганца (до 5,9 ПДК вышения нормативов - по цинку, меди и бенз(а)пирену. Превышений норматива ПДК пределами С33 за время всего периода наблюдения не обнаружено, загрязнение носило локальный характер.

В качестве дополнительной оценки степени аэротеногенного воздействия на исследованную территорию производили расчет суммарного индекса загрязнения снежного покрова $(\mathrm{Zc})$, который представляет собой сумму превышений концентраций веществ над их фоновым уровнем [22, 23].

При значениях более 32 предполагают увеличение риска заболеваемости населения (средний уровень воздействия), при значениях Zc более 128 территорию относят к чрезвычайно опасной категории загрязнения. Так, согласно полученным значениям Zc, для СЗ3 СЛПК отмечается высокий уровень техногенной нагрузки: максимальные значения превышали 300. На границе С33 с севера данный показатель значительно ниже и составляет 128-135. На южной границе СЗ3 этот показатель меньше 128.

Согласно средним значениям расчетов суммарного индекса загрязнения за 2015-2016 гг. и 2018-2019 гг. в районе влияния выбросов предприятия были условно выделены зоны с различным уровнем техногенной нагрузки (рис. 4):

I зона очень высокого воздействия включает территорию С33 АО «Монди СЛПК» с распространением на север и северо-восток от границы СЗ3 на 3,5 км;

II зона высокого воздействия выбросов - охватывает территорию от границ первой зоны на расстояние до 8-9 км на север и северо-восток от границы C33;

III зона среднего воздействия выбросов - охватывает территорию от границ второй зоны на расстояние до 11 км на север и северо-восток от границ С33;

IV зона за пределами зоны III, где отсутствует либо слабое воздействие выбросов предприятия (вблизи границы зоны).

Проведен анализ изменения площадного распространения зон воздействия на прилегающие к АО «Монди СЛПК» территории. С помощью картографических средств рассчитаны площади трех зон воздействия для начального периода мониторинга (20012002 гг.), перед реализацией программы «STEP» (2006-2007 гг.) и после значительной реконструкции предприятия (расчет средних параметров расположения зон воздействия за 2015-2016 гг. и 2018-2019 гг. (табл. 6).

Таблица 6. Площуади зон воздействия (км²), рассчитанные на основе суммарного индекса загрязнения $(\mathrm{Zc})$

Table 6. Areas of impact zones $\left(\mathrm{km}^{2}\right)$ calculated on the basis of the total pollution index $(Z c)$

\begin{tabular}{|c|c|c|c|}
\hline $\begin{array}{c}\text { Период исследования } \\
\text { Study period }\end{array}$ & I (128) & II (64) & III (32) \\
\hline $2001-2002$ & 23 & 114 & 300 \\
\hline $2006-2007$ & 31 & 142 & 274 \\
\hline $\bar{x}^{*}(2015-2016 ; 2018-2019)$ & 28 & 102 & 174 \\
\hline
\end{tabular}

* - $\bar{x}$ среднее значение за 2 года/average value for two years. 


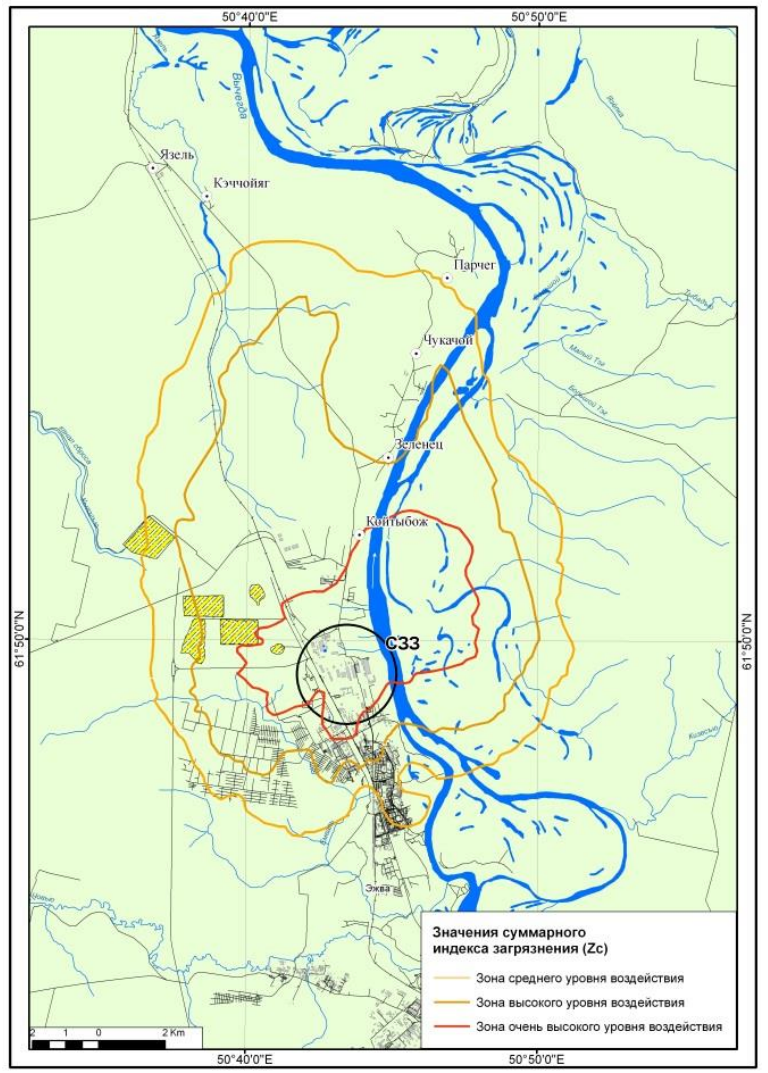

Таким образом, площади зон воздействия выбросов предприятия значительно изменились с начала мониторинга. При том, что зона очень высокого воздействия за счет преобладания пылевых компонентов, которые оседают вблизи к источнику эмиссии предприятия хоть и сократилась в сравнении с 2007 г. незначительно, другие зоны значительно уменьшились по площади за счет более рассеивающихся компонентов. Площадь зоны I (очень высокого воздействия) по данным 2015-2019 гг. уменьшилась в минимальной степени - на 9,7 \%. За тот же период площадь зоны II (сильного воздействия) уменьшилась на 28,2 \%, зоны III (среднего воздействия) - на 36,5 \% (рис. 5).

Наглядный анализ границы III зоны воздействия выбросов предприятия для разных лет показывает, насколько сократилась область воздействия, начиная с начала периода мониторинга, в первую очередь, в связи с уменьшением объема выбрасываемых в атмосферу веществ (рис. 5).

Pис. 4. Зоны аэрогенного воздействия эмиссии предприятия за 2016 и 2019 г2.

Fig. 4. Zones of aerogenic impact of the company's emissions for 2016 and 2019
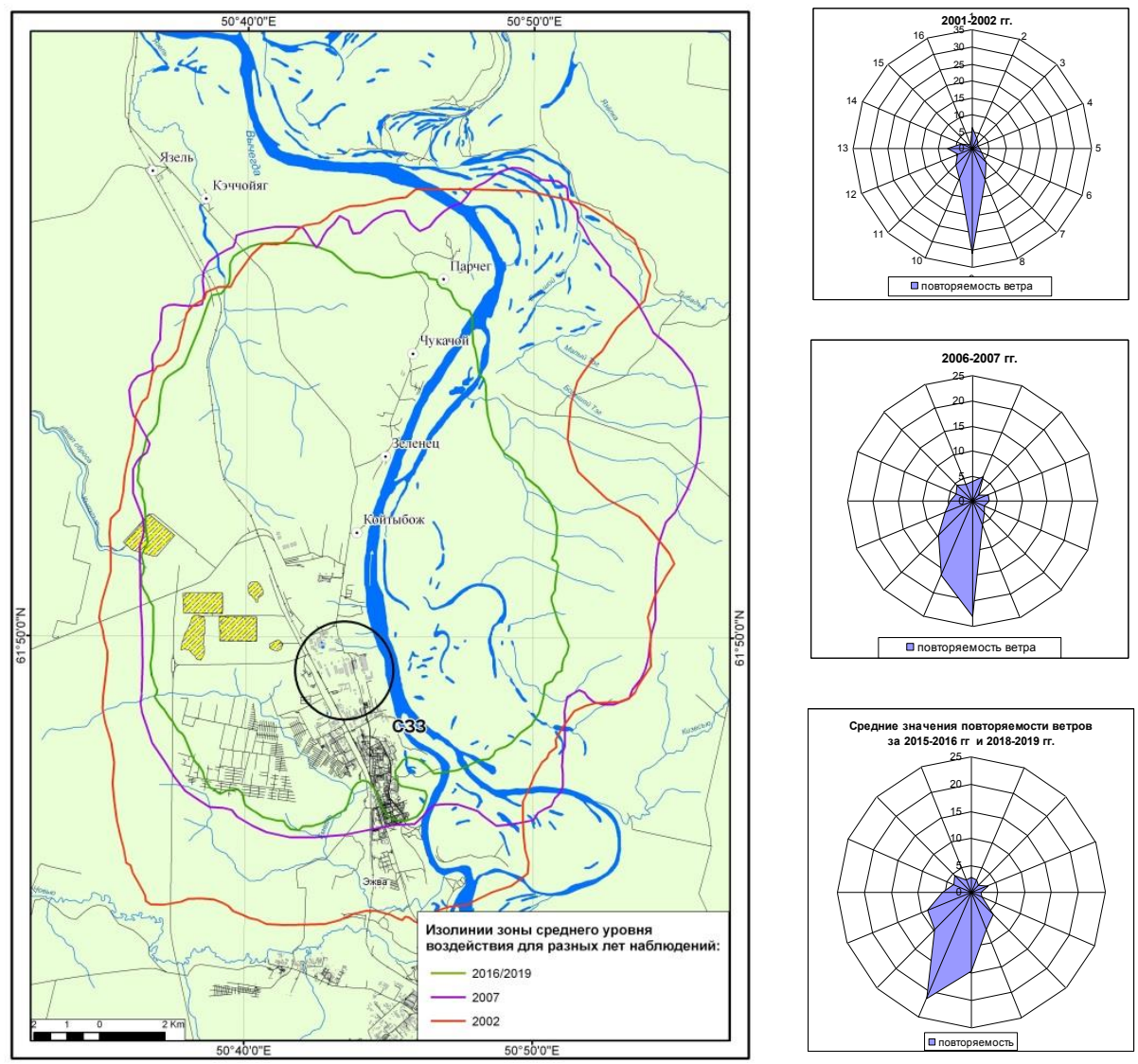

Рис. 5. Карта-схема расположения границы ІІІ зоны по интенсивности воздействия выбросов и «розы ветров» для соответствуюших зимних периодов

Fig. 5. Map-diagram of the zone III border location by the intensity of the impact of emissions a benz[a]pyrene and "wind rose» for the corresponding winter periods 
Очевидно, на распространение зон и фактор рассеивания повлияли метеорологические параметры, в частности ветровой режим. В сравнении с последними данными зоны воздействия распространялись дальше от источника эмиссии на восток и север. Также в последние годы наблюдалось снижение северных направлений ветров в зимнее время, поэтому шлейф от выбросов АО «Монди СЛПК» в меньшей степени стал уходить на юг от СЗ3, чем ранее, в 2001-2002 гг. Жилая застройка Эжвинского района города Сыктывкара с учетом «розы ветров» в настоящее время находится в зоне среднего воздействия.

\section{Заключение}

Представлены результаты экохимического мониторинга снежного покрова в зоне аэротехногенного воздействия выбросов АО «Монди СЛПК». Дана общая характеристика распределения индивидуальных компонентов выбросов относительно центра эмиссии. Длительный мониторинг снежного покрова в импактной и санитарно-защитной зонах предприятия позволил провести анализ динамики аэротехногенной нагрузки на территорию.

Снег с территории предприятия характеризуется щелочной реакцией за счет поступления гидрокарбонатной пыли, соединений кальция и магния. Ионные соотношения в талой воде весьма сильно отличны от таковых на условно фоновой территории. В качестве катионов преобладают ионы натрия, анионов - гидрокарбонат-ионы.

Результаты расчета модулей поступления веществ на территорию предприятия в 2019 г. показали наиболее низкий уровень загрязнения снежного по-

\section{СПИСОК ЛИТЕРАТУРЫ}

1. Atmospheric deposition: sampling procedures, analytical methods, and main recent findings from the scientific literature / M. Amodio, S. Catino, P.R. Dambruoso, G. Gennaro, A. Di Gilio, P. Giungato, E. Laiola, A. Marzocca, A. Mazzone, A. Sardaro, M. Tutino // Advances in Meteorology. - 2014. - V. 2014. - 27 p. DOI: 10.1155/2014/161730

2. Котова Е.И. Влияние морского аэрозоля на состав снега прибрежной зоны западного сектора арктических морей // Успехи современного естествознания. - 2019. - № 10. - С. 158-163.

3. Winter and summer nitrous oxide and nitrogen oxides fluxes from a seasonally snow-covered subalpine meadow at Niwot Ridge, Colorado / G. Filippa, M. Freppaz, M.W. Williams, D. Helmig, D. Liptzin, B. Seok, B. Hall, K. Chowanski // Biogeochemistry. 2009. - № 95. - P.131-149.

4. Filimonova L.M., Parshin A.V., Bychinskii V.A. Air pollution assessment in the area of aluminum production by snow geochemical survey // Russian meteorology and hydrology. 2015. - V. 40 - № 10 - P. 691-698.

5. Пространственное распределение тяжелых металлов в пробах снега вокруг северодвинского промышленного района / Е.Ю. Яковлев, Е.Н. Зыкова, С.Б. Зыков, А.А. Очеретенко // Успехи современного естествознания. - 2019. - № 11. C. $179-184$.

6. Химический состав снега акватории озера Байкал и прилегающей территории / И.А. Белозерцева, И.Б. Воробьёва, Н.В. Власова, М.С. Янчук, Д.Н. Лопатина // География и природные ресурсы. - 2017. - № 1. - С. 90-99.

7. Мониторинг качества снегового покрова, как составляющей среды обитания населения г. Самары / О.В. Сазонова, И.Ф. Сухачева, Н.И. Дроздова, О.Н. Исакова, П.А. Сухачев, Л.Н. Вистяк // Фундаментальные исследования. - 2014. - № 10 (часть 1). - С. 174-179. крова за весь период наблюдений, 66 \% относительно объемов 2002 г. Отмечено значительное снижение содержания компонентов в снеге, начиная с 2016 г. после реконструкции предприятия. Наиболее значительное снижение загрязнения отмечается по следующим компонентам: ионы натрия, хлорид-ионы, сульфа-ионы, нитрат- и нитрит-ионы.

Пробы талой воды снежного покрова за пределами территории санитарно-защитной зоны не превышают санитарно-гигиенических нормативов для рыбохозяйственных водоемов (ПДКрх) для всех компонентов. Однако на территории СЗ3 для нирит-ионов, марганца, фенола, цинка, меди и бенз(а)пирена превышения ПДК наблюдались.

Составлены карты распределения выбросов макрои микрокомпонетов в снежном покрове исследованной территории. Согласно расчетам техногенной нагрузки на основе суммарного индекса загрязнения были выделены зоны воздействия. Аэротехногенное воздействие СЛПК по направлению результирующего вектора «розы ветров» для большинства поллютантов ограничивается расстоянием 11 км от границы С33. Площади зон воздействия, рассчитанные на основе суммарного индекса загрязнения снежного покрова в сравнении с результатами 2007 г., после программы «STEP» значительно сократились на 9,7\% для I зоны, на 28,2 и 36,5 \% для II и III зоны, соответственно.

В целом на основе результатов экохимического мониторинга снежного покрова показан тренд к снижению аэрогенного воздействия предприятия на прилегающую территорию.

8. Химический состав снега на урбанизированных территориях в условиях Крайнего Севера / Н.В. Салтан, Е.П. Шлапак, В.К. Жиров, О.Б. Гонтарь, Е.А. Святковская // Вестник МГТУ. - 2015. - Т. 18. - № 2. - С. 328-334.

9. Семенец Е.С., Свистов П.Ф., Талаш А.С. Химический состав атмосферных осадков российского заполярья // Известия Томского политехнического университета. Инжиниринг георесурсов. - 2017. - T. 328. - № 3. - C. 27-36.

10. Snow pollution in Lake Baikal water area in nearby land areas / I.A. Belozertseva, I.B. Vorobyeva, N.V. Vlasova, D.N. Lopatina, M.S. Yanchuk // Water Resources. - 2017. - V. 44. - P. 471-484.

11. Grebenshchikova V.I., Efimova N.V., Doroshkov A.A. Chemical composition of snow and soil in Svirsk city (Irkutsk Region, Pribaikal'e) // Environmental Earth Sciences. - 2017. - V. 76:712. DOI: $10.1007 / \mathrm{s} 12665-017-7056-0$.

12. The influence of forest and topography on snow accumulation and melt at the watershed-scale / G. Jost, M. Weiler, D.R. Gluns, Y. Alila // Journal of Hydrology. - 2007. - V. 347. - P. 101-115.

13. Василенко В.Н., Наумов И.М., Фридман Ш.Д. Мониторинг загрязнения снежного покрова. - Л.: Гидрометеоиздат, 1985. $181 \mathrm{c}$.

14. Атлас по климату и гидрологии Республики Коми. - М.: Дрофа; ДиК, 1997. - 116 с.

15. http://loadmap.net

16. Sumathi S., Hung Y.T. Treatment of pulp and paper mill wastes // Waste treatment in the process industries / Eds. L.K. Wang, Y.T. Hung, H.H. Lo, C. Yapijakis. - Boca Raton: Taylor\&Francis, 2006. - P. 453-497.

17. Оценка аэротехногенного загрязнения вблизи промышленных предприятий в тундровой (на примере г. Воркуты) / М.И. Василевич, Р.С. Василевич, Д.Н. Габов, Б.М. Кондратёнок // Геоэкология - 2019. - № 6. - С. 94-105. 
18. Miller J.D., Anderson H.A., Harriman R. The consequences of liming a highly acidified catchment in central Scotland // Acidic Depos.: Sci and Policy: Pap. 5th Int. Conf. V. 2. Water, Air, and Soil Pollution. - Goteborg, 26-30 June, 1995. - P. 1015-1020.

19. Давыдова Н.Д. Техногенная трансформация топогеосистем при воздействии пылегазовых эмиссий: автореф. ... д-ра географ. наук. - Иркутск: Ин-т географии СО РАН, 2001. - 53 с.

20. Химический состав снежного покрова на территории таежной зоны Республики Коми / М.И. Василевич, Б.Н. Кондратенок, В.А. Безносиков // Водные ресурсы. - 2011. - Т. 38. - № 4. C. 494-506.

21. Накопление полициклических ароматических углеводородов в снежном покрове вблизи предприятий топливно- энергетического комплекса вокруг г. Воркута / Д.Н. Габов, Е.В. Яковлева, М.И. Василевич, Р.С. Василевич // Геоэкология. - 2019. - № 1. - С. 24-37.

22. Сает Ю.Е., Ревич Б.А., Янин Е.П. Геохимия окружающей среды. - М.: Недра, 1990. - 335 с.

23. Snow cover study in the zone of influence of the Severonickel plant / M. Slipenchuk, S. Kirillov, E. Vorobievskaya, N. Sedova // Arctic: History and Modernity: 5th International Conference. IOP Conf. Series: Earth and Environmental Science. - 2020. DOI: 10.1088/1755-1315/539/1/012030.

Поступила 20.09.2021 г.

\section{Информация об авторах}

Василевич М.И., кандидат биологических наук, научный сотрудник группы компьютерных технологий и моделирования Института Биологии ФИЦ КНЦ УрО РАН.

Кондратёнок Б.М., кандидат химических наук, заместитель директора по научной работе Института Биологии ФИЦ КНЦ УрО РАН.

Очеретенко Д.П., главный эколог отдел охраны окружающей среды АО «Монди СЛПК».

Василевич P.C., кандидат биологических наук, старший научный сотрудник группы химии почв Института Биологии ФИЦ КНЦ УрО РАН.

Габов Д.Н., кандидат биологических наук, старший научный сотрудник экоаналитической лаборатории Института Биологии ФИЦ КНЦ УрО РАН.

Лодыгин Е.Д., доктор биологических наук, старший научный сотрудник группы химии почв Института Биологии ФИЦ КНЦ УрО РАН. 
UDC 504.3.054

\section{MONITORING OF AEROTECHNOGENIC IMPACT OF SYKTYVKAR TIMBER INDUSTRY COMPLEX}

Maria I. Vasilevich1, mvasilevich@ib.komisc.ru

Boris M. Kondratenok ${ }^{1}$, kondratenok@ib.komisc.ru

Dmitry P. Ocheretenko², dmitry.ocheretenko@mondigroup.com

Roman S. Vasilevich ${ }^{1}$, vasilevich.r.s@ib.komisc.ru

Dmitry N. Gabov 1 , gabov@ib.komisc.ru

\section{Evgeny D. Lodygin ${ }^{1}$,} lodigin@ib.komisc.ru

1 Institute of Biology, FRC, Komi SC UB RAS,

28, Kommunisticheskaya street, Syktyvkar, 167982, Russia.

2 Mondi Syktyvkar JSC,

2, Bumazhnikov avenue, Syktyvkar, 167026, Russia.

The relevance of the research is caused by the need to assess the level of impact of a large pulp and paper enterprise located north of the Ezhvinsky district of Syktyvkar on the basis of ecochemical analysis of winter precipitation (snow), to show the feasibility of using this approach in environmental studies.

The main aim is to show the dynamics of the aerotechnogenic load on the territory near the Syktyvkar timber industry complex based on the data on snow cover chemical composition during the monitoring period.

Objects: snowpack samples, selected in the zone of influence of emissions of Mondi Syktyvkar JSC and conditionally background areas. Methods: snow survey using transect, adhering to constant sampling points, application of analytical methods according to the air pollution control manual (GD 52.04.186-89), cartographic methods for estimating the spread of pollution in the snow cover using the interpolation method (inverse weighted distance method), application of map algebra for calculating the areas of impact zones.

Results. The authors present the results of ecochemical monitoring of snow cover in the zone of aerotechnogenic impact of emissions Mondi Syktyvkar JSC for a multi-year period. A general description of the distribution of individual components of emissions relative to the emission center is given. Long-term monitoring of snow cover in the impact and sanitary protection zones of the enterprise allowed us to analyze the dynamics of the aerotechnogenic load on the territory. The results of the calculation of the modules of substances entering the territory of the enterprise in 2019 showed the lowest level of contamination of the snow cover for the entire observation period, $66 \%$ compared to the volumes of 2002. A significant decrease in the content of components in the snow was noted, starting in 2016 after the reconstruction of the enterprise. Samples of snowmelt water outside the territory of the sanitary protection zone do not exceed the sanitary and hygienic standards for fisheries reservoirs for all components. In general, based on the results of ecochemical monitoring of snow cover, the trend towards reducing the aerogenic impact of the enterprise on the adjacent territory is shown.

\section{Key words:}

Snow cover, ecochemical monitoring, pulp and paper enterprise, impact dynamics, impact zones.

\section{REFERENCES}

1. Amodio M., Catino S., Dambruoso P.R., Gennaro G., Di Gilio A., Giungato P., Laiola E., Marzocca A., Mazzone A., Sardaro A. Tutino M. Atmospheric deposition: sampling procedures, analytical methods, and main recent findings from the scientific literature. Advances in Meteorology, 2014, vol. 2014, 27 p.

2. Kotova E.I. Influence of marine aerosol on the composition of snow in the coastal zone of the western sector of the Arctic seas. Uspekhi sovremennogo estestvoznaniva, 2019, no. 10, pp. 158-163. In Rus.

3. Filippa G., Freppaz M., Williams M.W., Helmig D., Liptzin D., Seok B., Hall B., Chowanski K. Winter and summer nitrous oxide and nitrogen oxides fluxes from a seasonally snow-covered subalpine meadow at Niwot Ridge, Colorado. Biogeochemistry, 2009, no. 95, pp. 131-149.

4. Filimonova L.M., Parshin A.V., Bychinskii V.A. Air pollution assessment in the area of aluminum production by snow geochemical survey. Russian meteorology and hydrology, 2015, vol. 40, Iss. 10, pp. 691-698.

5. Yakovlev E.Yu., Zykova E.N., Zykov S.B., Ocheretenko A.A Spatial distribution of heavy metals in snow samples around Severodvinsk industrial district. Uspekhi sovremennogo estestvoznaniya, 2019, no. 11, pp. 179-184. In Rus.

6. Belozertseva I.A., Vorobyova I.B., Vlasova N.V., Yanchuk M.S., Lopatina D.N. Chemical composition of snow in the water area of Lake Baikal and the surrounding area. Geography and natural resources, 2017, no. 1, pp. 90-99. In Rus.

7. Sazonova O.V., Sukhacheva I.F., Drozdova N.I., Isakova O.N., Sukhachev P.A., Vistyak L.N. Monitoring the quality of snow cover as a component of the habitat of the population of Samara. Fundamentalnye issledovaniya, 2014, no. 10, pp. 174-179. In Rus.

8. Saltan N.V., Shlapak E.P., Zhirov V.K., Gontar O.B., Svyatkovskaya E.A. Chemical composition of snow in urbanized areas in the Far North. Vestnik MGTU, 2015, vol. 18, no. 2, pp. 328-334. In Rus. 
9. Semenets E.S., Svistov P.F., Talash A.S. Chemical composition of atmospheric precipitation in the Russian Arctic. Bulletin of the Tomsk Polytechnic University. Geo Assets Engineering, 2017, vol. 328, no. 3, pp. 27-36. In Rus.

10. Belozertseva I.A., Vorobyeva I.B., Vlasova N.V., Lopatina D.N., Yanchuk M.S. Snow pollution in Lake Baikal water area in nearby land areas. Water Resources, 2017, vol. 44, pp. 471-484.

11. Grebenshchikova V.I., Efimova N.V., Doroshkov A.A. Chemical composition of snow and soil in Svirsk city (Irkutsk Region, Pribaikal'e). Environmental Earth Sciences, 2017, vol. 76 (720).

12. Jost G., Weiler M., Gluns D.R., Alila Y. The influence of forest and topography on snow accumulation and melt at the watershedscale. Journal of Hydrology, 2007, vol. 347, pp. 101-115.

13. Vasilenko V.N., Naumov I.M., Fridman Sh.D. Monitoring zagryazneniya snezhnogo pokrova [Monitoring of snow cover pollution]. Leningrad, Gidrometeoizdat Publ., 1985. 181 p.

14. Atlas po klimatu i gidrologii Respubliki Komi [Atlas of climate and hydrology of the Komi Republic]. Moscow, Drofa; DiK Publ., 1997. $116 \mathrm{p}$.

15. http://loadmap.net

16. Sumathi S., Hung Y.T. Treatment of pulp and paper mill wastes. Waste treatment in the process industries Eds. L.K. Wang, Y.T. Hung, H.H. Lo, C. Yapijakis. Boca Raton, Taylor\&Francis, 2006. pp. 453-497.

17. Vasilevich M.I., Vasilevich R.S., Gabov D.N., Kondratyonok B.M. Otsenka aerotekhnogennogo zagryazneniya vblizi promyshlennykh predpriyatiy $v$ tundrovoy (na primere $g$. Vorkuty') [Assessment of aerotechnogenic pollution near industrial enterprises in tundra (on the example of Vorkuta)]. Geoekologiya, 2019, no 6, pp. 94-105.
18. Miller J.D., Anderson H.A., Harriman R. The consequences of liming a highly acidified catchment in central Scotland. Pap. $5^{\text {th }}$ Int. Conf. Acidic Depos.: Sci and Policy. Vol. 2. Water, Air, and Soil Pollution. Goteborg, 26-30 June, 1995. pp. 1015-1020.

19. Davydova N.D. Tekhnogennaya transformatsiya topogeosistem pri vozdeystvii plegazovykh emissiy. Avtoreferat Dis. Kand. nauk [Technogenic transformation of topogeodesical when exposed to dust and gas emissions. Cand. Diss. Abstract]. Irkutsk, 2001. 53 p.

20. Vasilevich M.I., Kondratenok B.N., Beznosikov V.A. Khimicheskiy sostav snezhnogo pokrova na territorii taezhnoy zony Respubliki Komi [Chemical composition of snow cover in the taiga zone of the Komi Republic]. Vodnye resursy, 2011, vol. 38, no. 4, pp. 494-506.

21. Gabov D.N., Yakovleva E.V., Vasilevich M.I., Vasilevich R.S. Accumulation of polycyclic aromatic hydrocarbons in the snow cover near the enterprises of the fuel and energy complex around Vorkuta. Geoekologiya, 2019, no. 1, pp. 24-37. In Rus

22. Saet Yu.E., Revich B.A., Yanin E.P. Geokhimiya okruzhayushhey sredy [Geochemistry of the environment]. Moscow, Nedra Publ., 1990. $335 \mathrm{p}$

23. Slipenchuk M., Kirillov S., Vorobievskaya E., Sedova N. Snow cover study in the zone of influence of the Severonickel plant. $5^{\text {th }}$ International Conference. Arctic: History and Modernity. IOP Conf. Series: Earth and Environmental Science, 2020. DOI: $10.1088 / 1755-1315 / 539 / 1 / 012030$

Received: 20 September 2021.

\section{Information about the authors}

Maria I. Vasilevich, Cand. Sc., researcher, Institute of Biology, FRC, Komi SC UB RAS.

Boris M. Kondratenok, Cand. Sc., deputy director, Institute of Biology, FRC, Komi SC UB RAS.

Dmitry P. Ocheretenko, main ecologist, Mondi Syktyvkar JSC.

Roman S. Vasilevich, Cand. Sc., senior researcher, Institute of Biology, FRC, Komi SC UB RAS.

Dmitry N. Gabov, Cand. Sc., senior researcher, Institute of Biology, FRC, Komi SC UB RAS

Evgeny D. Lodygin, Dr. Sc., senior researcher, Institute of Biology, FRC, Komi SC UB RAS. 